\title{
Alternative business models for flood risk management infrastructure
}

\author{
Claire Walsh ${ }^{1, a}$, Steven Burke ${ }^{2}$, Stephanie Glendinning ${ }^{1}$ and Richard Dawson ${ }^{1}$ \\ ${ }^{1}$ Centre for Earth Systems Engineering Research, School of Civil Engineering and Geosciences, Newcastle University, Newcastle upon \\ Tyne, NE1 7RU, UK. \\ ${ }^{2}$ Parsons Brinkerhof 29 Cathedral Road, Cardiff, CF119HA, UK
}

\begin{abstract}
Over the next 100 years, it is estimated that England will need $£ 0.6-1$ bn annual investment to manage flood and coastal erosion risk. Given constraints on central government spending following the 2008 financial crisis, the full burden of this is unlikely to be met by government alone. There is therefore a need to consider the potential for alternative business models for flood risk management infrastructure. An infrastructure business model describes how value is created, delivered and captured over the life cycle of the infrastructure system - this includes but is not limited to funding and financing. Alternative business models are starting to emerge across a range of infrastructure sectors, predominantly motivated by two key factors: (i) mainstream approaches do not deliver the benefits that communities want, (ii) tax payer funds are too constrained to deliver all the infrastructure investment that is sought. This paper presents and discusses a number of alternative business models for flood risk management infrastructure. Those currently under consideration focus on funding and financing, important though these issues are, it is only by capturing social, environmental and other values of infrastructure will flood risk stakeholders be able to identify approaches that are best suited to deliver their objectives and for alternative business models to emerge in practise.
\end{abstract}

\section{Introduction}

Over the next 100 years, the cost of implementing activities to manage flood and coastal erosion risk in England has been estimated at $£ 620 \mathrm{~m}-£ 1000 \mathrm{~m}$ a year [1]. This considers only on activity to manage flood and coastal erosion risk where direct economic benefits are greater than costs. Given constraints on central government financing post the 2008 economic crisis, it has become clear that the projected investment costs are unlikely to be continually covered by the Government. For example, in the agreement secured by Defra on capital funding for flood defences from 2015/6 to $2020 / 21$, levels would be around 5\% below 2009/10 and 2010/11 peaks in real terms [2]. There is therefore a requirement for alternative financing and funding mechanisms i.e. business models to be sought. Funding relates to the revenue sources, which are used to pay for the costs of the infrastructure; whereas financing turns the revenue sources into capital that can be used.

This paper considers alternative business models for flood risk management infrastructure. Alternative business models consider new ways of funding and financing infrastructure, by a wider set of actors that could capture value from the infrastructure - not just economic, but social, environmental, cultural, political etc. This could be via a portfolio of mechanisms, involving a range of actors that include the public, private and third sectors as well as local communities. In Section 2 an introduction to business models, the uniqueness of infrastructure and finance and funding mechanisms is given. Section 3 presented the current business model structure for flood risk management infrastructure and in Section 4 some alternatives are presented and discussed. In the final section additional, wider elements of infrastructure value are explored. Many of the concepts and arguments presented are transferable to other countries and contexts, but the focus here is on a case study in England to explore the concepts in more detail.

\section{Business Models, Infrastructure, Finance and Funding}

\subsection{Business Models}

The term 'business model' has become increasingly popular in recent years, yet its construct is highly debated. [3] summarises how the term is used in the literature. First, it is used to frame an empirical analysis without being defined [4]. Second, they are often directly related to firms that typify a particular type of approach to business - e.g. the Apple business model compared to the Samsung model [5]. Third, the concept is related to debates over strategy informed by the adoption of new technology [6]. Fourth, to develop a comparative approach to understanding business behaviour and performance $[5,7]$. Business models are not just about funding and financing, but capture wider issues such as social and economic values, governance and regulation.

\subsection{Uniqueness of infrastructure}

Alternative business models for infrastructure are not straight forward given the following nature of infrastructure assets and systems [3]:

-Infrastructure life cycle: the complex and multiphased lifecycle of projects may require different business models for different phases;

\footnotetext{
${ }^{\mathrm{a}}$ Corresponding author: claire.walsh@ncl.ac.uk
} 
-Long term legacy: infrastructure assets have long lives; legacy inherent in decisions about the provision of assets can lead to a path of dependency which may reduce future options;

-Necessity of service: users depend on infrastructure services;

-Public sector involvement: government are often involved in the delivery or operation of infrastructure;

-Natural monopolies: the economies of scale can benefit from monopolistic provision of service to avoid wasteful use of resources, universal coverage of a service and to ensure a secure customer base;

-Financial profile: infrastructure is capital intensive, with high initial costs and periodic maintenance;

-Complex value: infrastructure provides direct, tangible economic returns but also wider social and environmental benefits;

-Multiple agents: vast array of interested stakeholders at various stages of the life cycle;

-Public good: many systems are non-excludable and non-rivalrous.

An infrastructure business model describes how value is created, delivered and captured over the life cycle of the infrastructure system [3]. Important as they are, this is not limited to the funding and financing but to social and environmental values. The term value is used, as opposed to benefit, as this better reflects the regard that something is held to deserve, its importance and worth. This includes consideration of the size of benefit, but also the idea that some benefits may be more important than others. Identifying and understanding how value is created, where it is created and who the value is created for, helps to identify possible mechanisms (financial or otherwise) to capture these values and hence develop alternative business models for infrastructure. Alternative business models are starting to emerge across a range of infrastructure sectors, currently these are motivated by two key factors: (i) mainstream approaches do not deliver benefits that communities want, (ii) tax payer funds are too constrained to deliver all the infrastructure investment that is sought.

\subsection{Financing and funding of infrastructure}

In general demand for infrastructure will continue to grow with increasing population and desires for better and more reliable assets and services [8]. For some of the reasons outlined above, historically investment in infrastructure has been government led. Although financial and governance arrangements for infrastructure projects do vary geographically, for example the United States and Australia traditionally had great private sector finance than the UK [9]. Throughout the late twentieth century there has been an increasing trend towards the private sector owning and financing infrastructure assets, accelerated by public debt and deficits [10], with the state's role becoming that of a regulator e.g. privatisation of the water sector.

Traditional finance mechanisms include: capital grants, where money is provided by the government with repayment being in the form of demonstrating achievement of the objectives; user charges: payments for using the infrastructure are used to repay the investment; Public Works Loan Board: Local Authority borrowing; grant funding: from governments or charities at different levels; partnerships: multiple forms of finance for shared projects. Table 1 summarises a variety of different infrastructure funding and financing practices have emerged to complement the more traditional mechanisms.

\begin{tabular}{|c|c|}
\hline Type & Examples \\
\hline Taxes and fees & Special assessments, user charges \\
\hline Grants & $\begin{array}{c}\text { Range of grant programmes at } \\
\text { multiple levels }\end{array}$ \\
\hline Debt finance & $\begin{array}{c}\text { Revenue bonds, National Loan } \\
\text { Funds e.g. Public Works Loans } \\
\text { Board }\end{array}$ \\
\hline Tax incentives & $\begin{array}{l}\text { New housing credits, tax credit } \\
\text { bonds, enterprise zones }\end{array}$ \\
\hline Developer fees & Infrastructure levies \\
\hline $\begin{array}{c}\text { Platforms for } \\
\text { institutional investors }\end{array}$ & $\begin{array}{l}\text { State infrastructure banks, } \\
\text { sovereign wealth funds }\end{array}$ \\
\hline $\begin{array}{l}\text { Value capture } \\
\text { mechanisms }\end{array}$ & $\begin{array}{l}\text { Tax increment financing, } \\
\text { accelerated development zones }\end{array}$ \\
\hline $\begin{array}{l}\text { Public private } \\
\text { partnerships }\end{array}$ & $\begin{array}{c}\text { Private finance initiative, design- } \\
\text { build-operate-transfer }\end{array}$ \\
\hline $\begin{array}{l}\text { Asset leverage and } \\
\text { leasing mechanisms }\end{array}$ & $\begin{array}{l}\text { Asset leasing, local asset-backed } \\
\text { vehicles }\end{array}$ \\
\hline $\begin{array}{c}\text { Revolving } \\
\text { infrastructure funds }\end{array}$ & $\begin{array}{c}\text { Infrastructure trusts, earnback and } \\
\text { gainsharing }\end{array}$ \\
\hline Crowd funding & $\begin{array}{c}\text { Capital raised from a large number } \\
\text { of people }\end{array}$ \\
\hline
\end{tabular}

Table 1. Infrastructure funding and financing options (adapted from [9]).

\section{Existing Business Model for Flood Risk Management}

Table 2 outlines the organisations and bodies that have an involvement in flood risk management in England and Wales at various scales.

In general, funding for Flood and Coastal Erosion Management (FCERM) in England comes from Central Government. This typically originates from Defra, which passes this funding on as Grant-in-Aid, the typical mechanism for financing a Non-Departmental Public Body such as the Environment Agency (EA) in England. The EA will spend most of this grant directly on FCERM or pass some, also as grants to local authorities or internal drainage boards. For their role of managing the risk of all local causes of floods, Defra also transfers funding to Lead Local Flood Authorities. Other mechanisms of funding include levies in local authorities raised by the EA's Regional Flood and Coastal Committees; Partnership Funding schemes, as recommended by the Pitt Review [12] which allow Central Government to contribute to a range of schemes rather than meeting the full cost, with local communities raising the additional costs; internal drainage boards can raise funds from Drainage Charges and Special Levies; the EA can raise 
other income from Internal Drainage Board Precepts; General Drainage Charges and Sales of Assets [13].

Figure 1 shows that expenditure on flood risk management reached a peak in 2010/11. Between 201011 and 2013-14, central government funding for flood risk management fell, by $18 \%$ for capital and by $10 \%$ for revenue in cash terms [11]. The need to respond to emergency situations and to repair assets following the winter 2014/15 floods required additional funding; an extra $£ 270$ million to be distributed between $2013-14$ and 2015-16 [11].

\begin{tabular}{|c|c|}
\hline \multicolumn{2}{|r|}{ National Scale } \\
\hline $\begin{array}{l}\text { Department } \\
\text { for } \\
\text { Environment, } \\
\text { Food and } \\
\text { Rural Affairs } \\
\text { (DEFRA) }\end{array}$ & $\begin{array}{l}\text { National policy for flood and coastal } \\
\text { protection. Funds flood risk management } \\
\text { authorities }\end{array}$ \\
\hline $\begin{array}{l}\text { Environment } \\
\text { Agency }\end{array}$ & $\begin{array}{l}\text { Strategic overview of all flooding sources. } \\
\text { Operational responsibility to manage } \\
\text { fluvial and coastal flooding. }\end{array}$ \\
\hline $\begin{array}{l}\text { Department } \\
\text { for } \\
\text { Communities } \\
\text { and Local } \\
\text { Government }\end{array}$ & $\begin{array}{l}\text { Sets national planning framework for } \\
\text { development and flood risk. Ensures flood } \\
\text { risk and the planning process overlap. } \\
\text { Coordinates local authority recovery } \\
\text { following flood events. }\end{array}$ \\
\hline Cabinet Office & $\begin{array}{llr}\begin{array}{l}\text { Develops } \\
\text { programmes. }\end{array} & \text { cross-sector } & \text { resilience } \\
\end{array}$ \\
\hline \multicolumn{2}{|r|}{ Regional Scale } \\
\hline $\begin{array}{l}\text { Regional flood } \\
\text { and coastal } \\
\text { committees }\end{array}$ & $\begin{array}{c}\text { Ensures plans to identify, communicate and } \\
\text { manage flood risk across catchment and } \\
\text { shoreline areas exits. Promote efficient and } \\
\text { targeted investment. Links flood risk } \\
\text { management authorities and other relevant } \\
\text { bodies. }\end{array}$ \\
\hline \multicolumn{2}{|r|}{ Local Scale } \\
\hline $\begin{array}{l}\text { Lead local } \\
\quad \text { flood } \\
\text { authorities }\end{array}$ & $\begin{array}{l}\text { Prepare local flood risk management } \\
\text { strategies. Maintain flood risk asset } \\
\text { register. Manage flood risk from surface } \\
\text { water, groundwater and ordinary } \\
\text { watercourses. }\end{array}$ \\
\hline $\begin{array}{l}\text { Local } \\
\text { resilience } \\
\text { forums }\end{array}$ & $\begin{array}{l}\text { Multi-agency partnerships that plan and } \\
\text { prepare for local flooding incidents. }\end{array}$ \\
\hline $\begin{array}{l}\text { District and } \\
\text { borough } \\
\text { councils }\end{array}$ & $\begin{array}{l}\text { Ensure new development is safe, flood } \\
\text { resilient, does not increase flood risk and } \\
\text { where possible reduce risk. }\end{array}$ \\
\hline $\begin{array}{l}\text { Internal } \\
\text { drainage } \\
\text { boards }\end{array}$ & $\begin{array}{l}\text { Independent public bodies responsible for } \\
\text { water-level management in low-lying areas } \\
\text { and regulation of activities on ordinary } \\
\text { watercourses within drainage districts. }\end{array}$ \\
\hline
\end{tabular}

Table 2. Organisations and bodies involved in flood risk management in England and Wales (adapted from [11]).

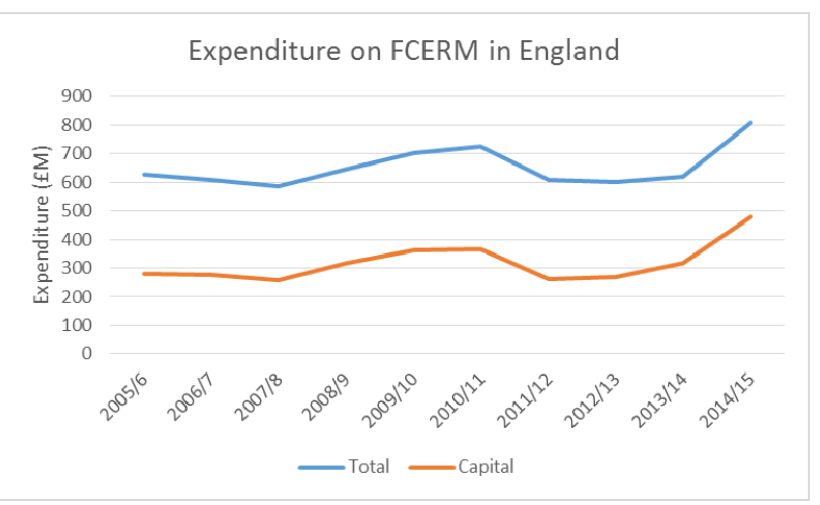

Figure 1. Expenditure on FCERM in England, 2005/6 to 2014/5. Data source: [13].

If considering surface water flood risk management projects within an urban area, the funding landscape is different (see Figure 2). The Lead Local Flood Authority (typically a Local Authority) are the central and coordinating delivery agent. Grants are provided by Central Government via Defra as described above, supplemented with other third party grants. Developers of areas have to make a mandatory payment such as the Community Infrastructure Levy (CIL) to the local authority to help deliver infrastructure to support the development of the area. Other direct payments may also be received from water companies, property owners and other third-party actors such as environmental bodies.

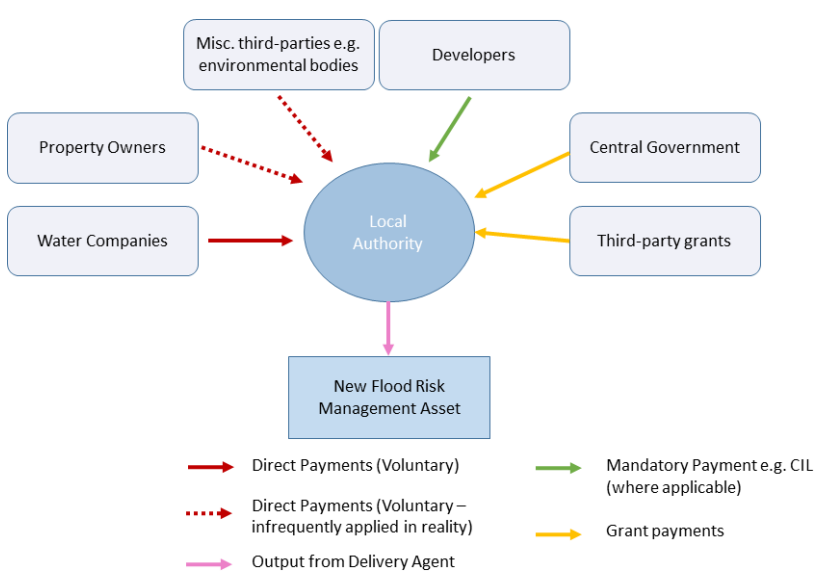

Figure 2. Existing business model for surface water flood risk management. (CIL is a Community Infrastructure Levy)

\section{Alternative Business Models for Flood Risk Management}

Maintaining a focus on the management of surface water flood risk, six alternative business models are considered. Each is presented with an illustration highlighting the coordinating delivery agent and flows of economic input and value from other agents. 


\subsection{Water Service Company (WASCO) business model}

The Water Service Company (WASCO) business model is based upon the alternative catchment system operator approach presented by Helm (2015). The methodology considers distinct catchments as systems of interlinked components which require integrated management to realise optimum catchment benefits, recognising the value of embedded natural capital. Such a framework would help address three current issues with the division of water-management responsibilities in England and Wales. Firstly, that no on body has an holistic responsibility for water activities within an appropriately define geographical area; secondly, the legacy of dividing pollution control and flood risk management functions, and thirdly, that long-term flood defence policy is under short-term funding control of HM Treasury [14]. Helm [14] proposes three solutions to the issues he identified. The first a competition model whereby the sector is further fragmented to increase competition in an unbundled commodity-based market. The second, a systems planning model is fundamentally different. Catchments comprise of natural capital assets that function in an integrated manner and can therefore not be traded on a marginal basis in the way that commodities are. A natural system requires active coordination and cannot be 'managed' by the selfcorrecting mechanisms of the Market. The third option is a combination of the first two - a system operator (public function) and competition to deliver coordinated functions and services (private function, largely marketdriven). In this water system operator, building and maintaining flood defence assets would be delivered by the competitive market. Figure 3 illustrates how a Water Service Company business model for flood risk management may emerge.

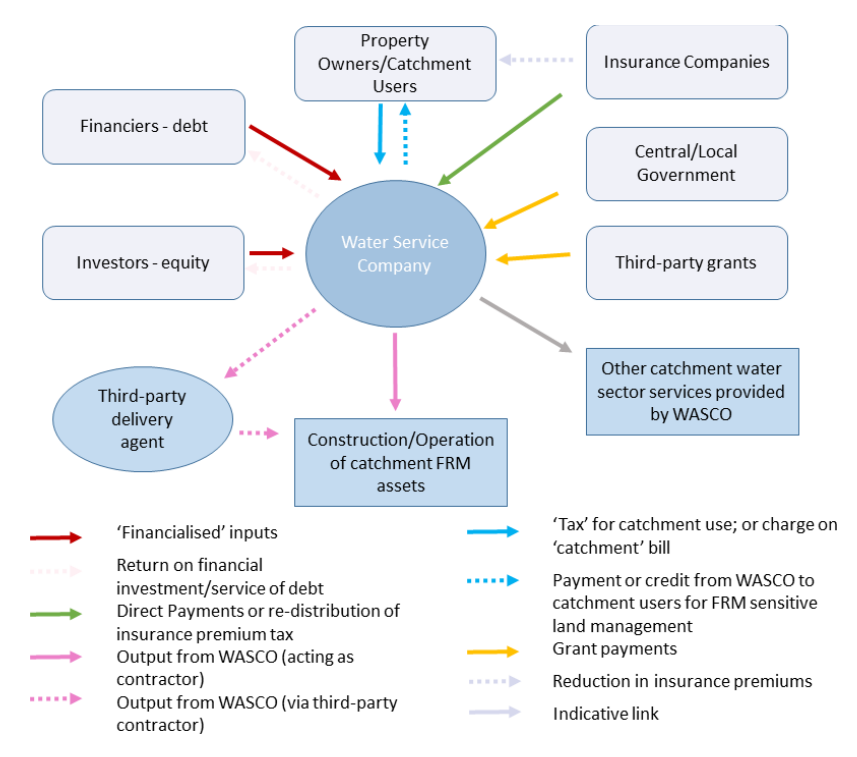

Figure 3. Water Service Company (WASCO) business model.
The creation of a Special Purpose Vehicle (SPV) as a means of financing and potentially operating and maintaining flood risk management infrastructure is a concept that has been utilised in international infrastructure provision., as a derivative of the public private partnership and private finance initiative approaches. This method could be applied to both the WASCO business model (Figure 4) and the traditional flood risk management model (Figure 5). Furthermore, it could also be applied to any other business model that has a defined, reliable and long-term source of income, or an asset base that has the ability to attract third party private finance.

The traditional procurement of flood risk management infrastructure or services involves the government specifying the specification of the asset. The actual delivery of the asset or service is provided by private companies who tender for the contract. The ownership of the asset remains with the government body and they are responsible for the operation, maintenance, renewal and if necessary disposal of the asset. Implementation of a SPV and PPP/PFI arrangement would offer the following benefits: a) a faster implementation timetable - the private finance stream is typically faster than the constrained public one; b) reduction in whole life costs, the closer integration of the elements of project delivery, provided by a single entity enables greater control of the costs and hence more opportunity for costs to be reduced; c) effective division of risk, with risk apportioned to the party ablest to manage it; d) performance incentives, the appropriate risk division should incentivise the private sector elements to improve performance and increase efficiency.

SPVs have been implemented for the Pevensey Bay Coastal Defence Project and the Broadlands Flood Alleviation Scheme in the UK. Both schemes have SPVs whose role it is to finance, build and operate the flood alleviation schemes over contractually specific time periods. It could be envisaged that within the context of its use where the catchment managing agent would take the form of the Water Service Company. The Water Service Company would have the ability to make provisions for the payment of the service fee to the SPV via management of its own fee/tax charging systems, or indeed from the revenue sources provided by third party investors (e.g. pension funds) investing against the asset base. 


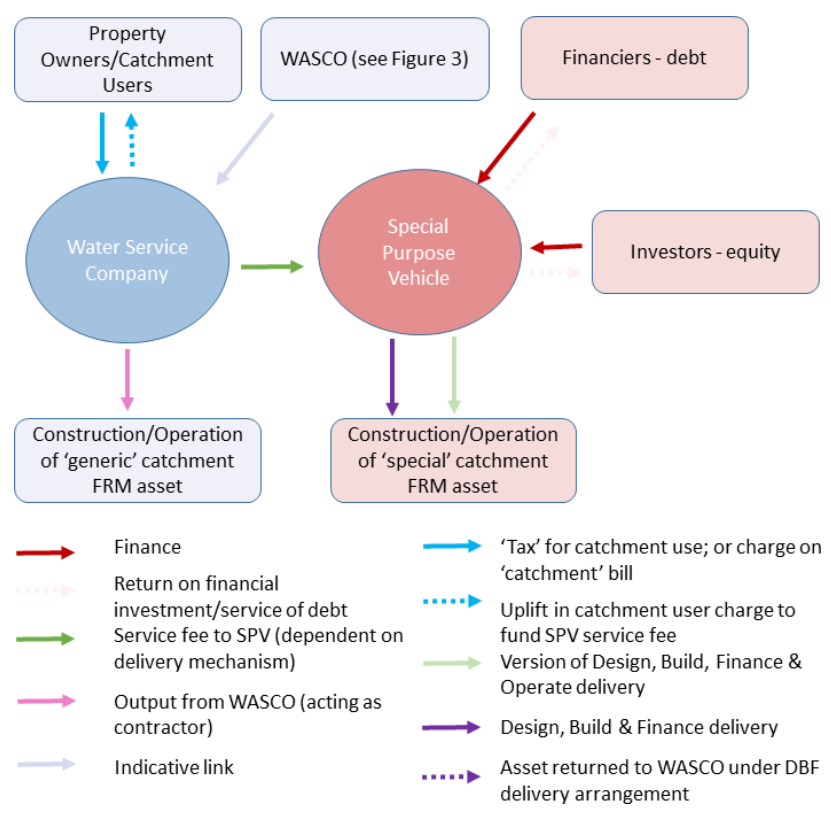

Figure 4. WASCO business model with Special Purpose Vehicle.

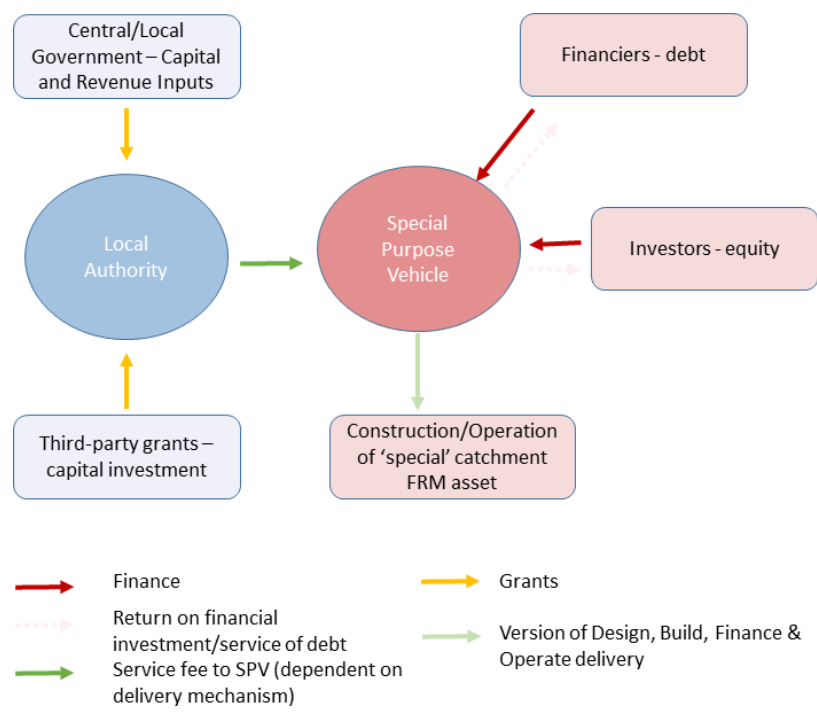

Figure 5. Traditional flood risk management business model with Special Purpose Vehicle.

\subsection{Stakeholder delivery}

The stakeholder delivery model (Figure 6) may ensure that public money is used across a greater number of flood risk management schemes. This in essence is similar to the partnership funding approach that is being advocated by Defra in England and Wales. A Local Enterprise Partnership is formed and comprises local businesses, property owners and Local Authorities, a pool of various stakeholders that include the lead flood authority who provides regulatory oversight as well as insurance companies, developers, sewerage undertakers, property owners and other catchment users. This organisation would have the ability to enter into relationships which enable the financing of flood risk management projects. There are three main advantages to stakeholders investing directly in the necessary infrastructure: i) they may be absolved from paying certain taxes and fees associated with the project; ii) stakeholder are providing meaningful input into investment decisions which may lead to their interest being better served; iii) local pooled funded may ensure that projects that had previously failed central government investment criteria, go ahead.

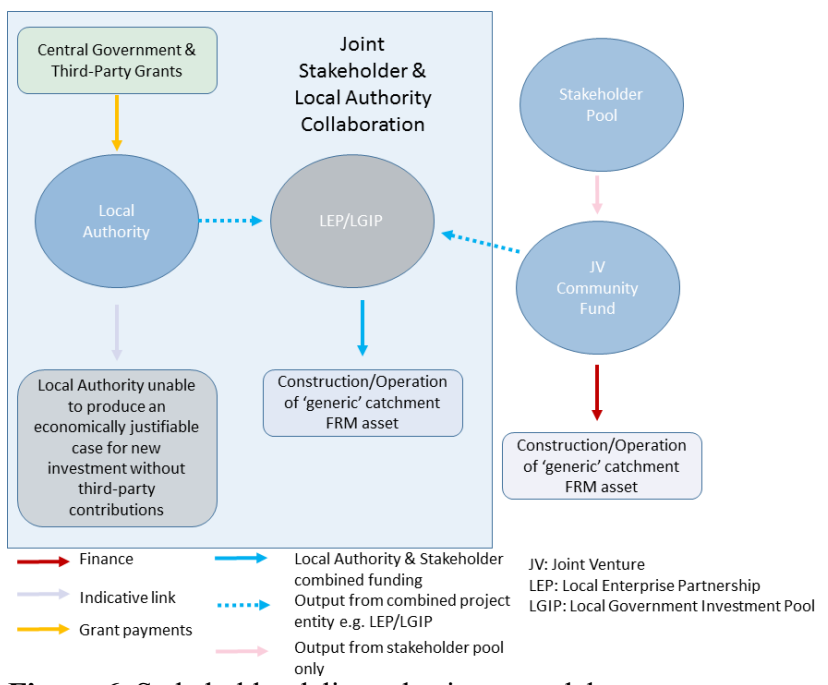

Figure 6. Stakeholder delivery business model.

\subsection{Financing through full cost recovery}

Full cost pricing involves the private sector fully recovering the cost of providing the financed flood risk management asset or service. As a general rule within such a business model, the actual cost of the asset or service are borne by increased user charges. Coordination of the finance from all parties would take place via a 'finance aggregator'. Figure 7 illustrates that property owners would not contribute to the costs directly, but indirectly through increased water bills, council tax and insurance premiums, which would allow the water company, local authority and insurance company but invest in the asset. Given it is a public good, it is unusual for infrastructure to be fully-funded by user-charging; therefore a subsidy by central government is also included to negate any socio-economic detriment that may arise for property owners who are unable to afford they increased water bills, council tax and insurance premiums.

In the longer term, insurance companies, water companies and local authorities will benefit from the infrastructure through a reduction in disruptions to services and reduced need to pay compensation. Other factors, such as climate change and new development, will also have implications for beneficiaries. The business model could evolve over time to reflect the changes to values, for example by altering indirect user charges. 


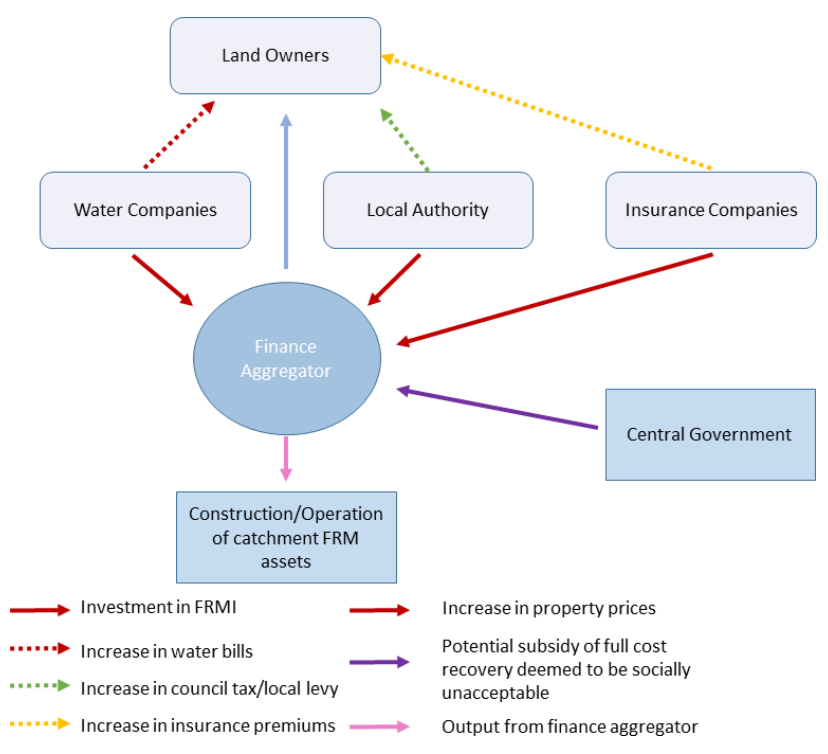

Figure 7. Full cost recovery business model.

\subsection{Financing by developers/landowners}

A simple but attractive proposition is that those who benefit from new or improvements made to local flood risk management schemes should paper for them. Figure 8 illustrates that initial capital outlay for new infrastructure is paid for by various landowners via savings, loans or subsidies. As compensation, landowners may receive a reduction in their water bills, home insurance premiums and a potential increase in property prices.

\subsection{Summary}

The six alternative business models for surface flood risk management may appear to be relatively simple, but practical implementation raises a number of challenges. The organisational framework of the UK water industry is deeply entrenched and would require fundamental reframing to allow these new models to emerge. For example, in the case of the WASCO, the Environment Agency in its current form would cease; a new catchment operator would take on its flood risk management responsibilities, as well as those of water companies, lead local flood authorities and land management agents. At present there are a lack of incentives for the actors included in the alternatives to adopt the measures and invest capital, particularly as current delivery of flood risk management is highly subsidised. Furthermore, the alternatives are missing a number of opportunities with still being focused purely on financial return and economic benefits, and ignoring the systemic properties of flood risk management infrastructure.

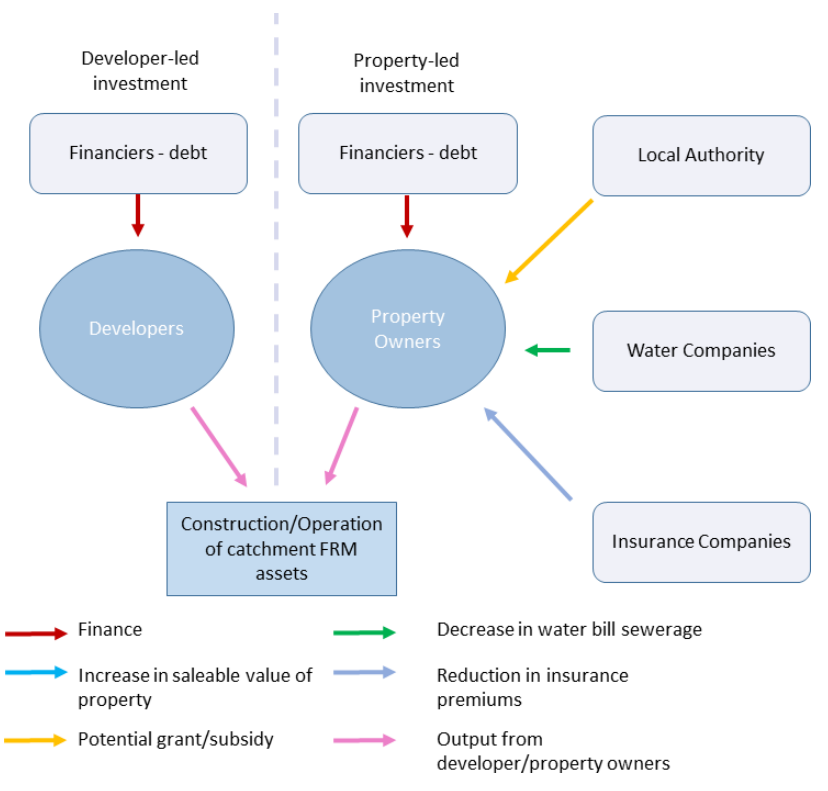

Figure 8. Development/property owner investment.

\section{Capturing wider value}

It is clear that investment in flood and coastal erosion risk management brings significant economic benefits by protecting homes, businesses agricultural land and infrastructure and hence reducing potential economic damages. For example, based on the estimated $£ 25$ billion investment required over the next 100 years in England the net present value (i.e. the difference between the economic benefit of the overall investment, and the cost of providing it) of the investment is estimated to be $£ 102$ billion over 100 years: an overall benefit to cost ratio of about 5 to 1 [1]. However, in addition, there are a number of social and environmental benefits that could be achieved and hence values captured that could be incorporate into alternative business models.

\subsection{Examples of alternative business models for local infrastructure}

A recent review of alternative business models for infrastructure $[15,16]$ has identified an increasing number of solutions and combinations for financing and funding, and lead organisations for local infrastructure. Examples are present in Table 3 for a range of infrastructures and in Table 4 for flood defence infrastructure. 


\begin{tabular}{|c|c|c|c|}
\hline Project & $\begin{array}{c}\text { Finance } \\
\text { Mechanism } \\
\text { (Capital } \\
\text { Investment) }\end{array}$ & $\begin{array}{c}\text { Funding } \\
\text { Mechanism } \\
\text { (Revenue } \\
\text { Source) }\end{array}$ & $\begin{array}{c}\text { Project } \\
\text { Lead }\end{array}$ \\
\hline $\begin{array}{c}\text { Broadband } 4 \\
\text { Rural North } \\
\text { (Telecom) }\end{array}$ & $\begin{array}{c}\text { Community } \\
\text { share } \\
\text { scheme }\end{array}$ & User charges & $\begin{array}{l}\text { Community } \\
\text { organisation }\end{array}$ \\
\hline $\begin{array}{l}\text { Crossrail } 2 \\
\text { (Railway) }\end{array}$ & $\begin{array}{c}\text { National } \\
\text { taxation } \\
\text { (capital), } \\
\text { Debt } \\
\text { financing: } \\
\text { Tax } \\
\text { Increment } \\
\text { Financing } \\
\text { (TIF) }\end{array}$ & $\begin{array}{c}\text { User } \\
\text { charges, } \\
\text { Land value } \\
\text { capture, } \\
\text { Local } \\
\text { levy/rates, } \\
\text { National } \\
\text { taxation } \\
\text { (revenue) }\end{array}$ & $\begin{array}{c}\text { Public } \\
\text { organisation }\end{array}$ \\
\hline $\begin{array}{c}\text { A92 } \\
\text { Upgrade } \\
\text { between } \\
\text { Dundee and } \\
\text { Arbroath } \\
\text { (Road) }\end{array}$ & $\begin{array}{l}\text { Private } \\
\text { Finance } \\
\text { Initiative }\end{array}$ & $\begin{array}{c}\text { Performance } \\
\text {-based } \\
\text { partnership }\end{array}$ & $\begin{array}{c}\text { Public- } \\
\text { private } \\
\text { organisation }\end{array}$ \\
\hline $\begin{array}{l}\text { Solar Panels } \\
\text { Scheme } \\
\text { (Energy- } \\
\text { Electricity) }\end{array}$ & Grants & $\begin{array}{c}\text { Pay-as-you- } \\
\text { save }\end{array}$ & Individuals \\
\hline
\end{tabular}

Table 3. Alternative business models for local infrastructure.

\begin{tabular}{|c|c|c|c|}
\hline Project & $\begin{array}{c}\text { Finance } \\
\text { Mechanism } \\
\text { (Capital } \\
\text { Investment) }\end{array}$ & $\begin{array}{c}\text { Funding } \\
\text { Mechanism } \\
\text { (Revenue } \\
\text { Source) }\end{array}$ & Project Lead \\
\hline The Wash & $\begin{array}{c}\text { National } \\
\text { taxation } \\
\text { (capital) }\end{array}$ & $\begin{array}{c}\text { Philanthropic } \\
\text { donations }\end{array}$ & $\begin{array}{c}\text { Community } \\
\text { organisation }\end{array}$ \\
\hline $\begin{array}{c}\text { Somerset Fen } \\
\text { Drainage }\end{array}$ & $\begin{array}{c}\text { National } \\
\text { taxation } \\
\text { (capital) }\end{array}$ & $\begin{array}{c}\text { Local } \\
\text { levy/rates }\end{array}$ & $\begin{array}{c}\text { Public } \\
\text { organisation }\end{array}$ \\
\hline $\begin{array}{c}\text { Pevensey Bay } \\
\text { Private } \\
\text { Finance } \\
\text { Initiative }\end{array}$ & $\begin{array}{c}\text { National } \\
\text { taxation Local } \\
\text { levy/rates }\end{array}$ & $\begin{array}{c}\text { Private } \\
\text { organisation }\end{array}$ \\
$\begin{array}{c}\text { Flood } \\
\text { Flleviation }\end{array}$ & $\begin{array}{c}\text { Private } \\
\text { Froject }\end{array}$ & $\begin{array}{c}\text { Nationce } \\
\text { Initiative } \\
\text { taxation Local } \\
\text { levy/rates }\end{array}$ & $\begin{array}{c}\text { Private } \\
\text { organisation }\end{array}$ \\
\hline $\begin{array}{c}\text { Cockermouth } \\
\text { Passive Flood } \\
\text { Defence }\end{array}$ & $\begin{array}{c}\text { National } \\
\text { taxation } \\
\text { (capital) }\end{array}$ & $\begin{array}{c}\text { Philanthropic } \\
\text { donations, } \\
\text { Local } \\
\text { levy/rates }\end{array}$ & $\begin{array}{c}\text { Community } \\
\text { organisation }\end{array}$ \\
\hline
\end{tabular}

Table 4. Alternative business models for local flood defence infrastructure.

For each of the examples, the value proposition is identified i.e. how the value is created and who the value is created for. The different types of values need to be understood; moving beyond the pure economics to wider social and environmental values (see Table 5). This is particularly important as it helps to identify alternative mechanisms to obtain a return on investment. Certain investors may require this to be a financial return e.g. payments from rent, or primary and secondary usage of the infrastructure. However, these might also include social or environmental returns on the investment. Looking beyond existing approaches to flood defence can provide inspiration for genuinely alternative approaches, and demonstrate that infrastructure services can be delivered in quite different ways.

Broadband 4 Rural North, for example, provides broadband in rural areas where the main telecommunication companies deemed it noneconomically viable to do so. Here the value was created through providing a leading service provision, additional capacity for future upgrades, donation of labour for construction in return for equity shares, and reduced delivery costs by landowners providing free access to installers, thereby shortening the distance for connections. Value was created for all residents, through access to the broadband service; installation was undertaken by local businesses retaining spending in the area; a Community Benefit Society agreement means the asset cannot be sold and needs to remain a benefit for the community. Shareholders are also eligible for tax relief on personal income tax.

\subsection{Cockermouth Passive Flood Defence}

The total cost of the scheme was $£ 4.45$ million; $£ 3.35$ million was a provided by Flood and Coastal Risk Management Grant in Aid, the additional contributions to this partnership scheme were: Local levy (£100k), Cumbria County Council (£600k), Allerdale Borough Council (£100k), Cockermouth Town Council (£120k) and the Cockermouth Flood Action Group and local people $(£ 215 \mathrm{k})$. A referendum was held in the town and residents voted to pay additional council tax to fund the scheme [17]. The value created was: flood defences to reduce the risk of damage to property and businesses; additional street improvement scheme to enhance the brand of the town $(£ 1 \mathrm{~m})$; maintaining heritage of town and environmental value of the Site of Special Scientific Interest (SSSI). The value was created for local residents and site of special scientific interest.

Different types of value begin to emerge for different actors. Table 5 suggests what some of these values are and who benefits from them. These include others beyond those who contributed financially to the funding the scheme. 


\begin{tabular}{|c|c|c|}
\hline Type of value & $\begin{array}{l}\text { Who is the } \\
\text { value for? }\end{array}$ & Examples of value \\
\hline \multirow[t]{4}{*}{ Economic } & Residents & $\begin{array}{l}\text { Reduced flood risk to } \\
\text { property, reduced } \\
\text { insurance premiums, } \\
\text { uplift in property value }\end{array}$ \\
\hline & Businesses & $\begin{array}{l}\text { Reduced flood risk to } \\
\text { assets, reduced } \\
\text { insurance premiums, } \\
\text { reduced risk of } \\
\text { disruption to trading or } \\
\text { supply chains }\end{array}$ \\
\hline & $\begin{array}{c}\text { Local } \\
\text { authority }\end{array}$ & $\begin{array}{c}\text { Increased visitor } \\
\text { numbers, higher } \\
\text { business rates }\end{array}$ \\
\hline & $\begin{array}{l}\text { Other } \\
\text { infrastructure } \\
\text { providers e.g. } \\
\text { Highways } \\
\text { Agency }\end{array}$ & $\begin{array}{l}\text { Protection of other } \\
\text { infrastructure assets }\end{array}$ \\
\hline Cultural & $\begin{array}{c}\text { Local } \\
\text { Authority }\end{array}$ & $\begin{array}{c}\text { Local pride in heritage } \\
\text { status }\end{array}$ \\
\hline Environmental & $\begin{array}{l}\text { Residents, } \\
\text { tourist } \\
\text { industry, }\end{array}$ & Maintaining the SSSI \\
\hline Political & $\begin{array}{l}\text { Natural } \\
\text { England }\end{array}$ & Protection of the SSSI. \\
\hline
\end{tabular}

Table 5. Different types of value associated with the Cockermouth flood defence scheme. Some outcomes may be achieved from multiple values, therefore care must be taken to avoid double-counting.

\subsection{Dimensions of value}

From the cases considered a number of elements related to value begin to emerge:

1 Resilience to extreme events is one of the key services provided by flood risk management infrastructure, yet existing business models struggle to capture this long term value.

2 Different classes/types of value emerge e.g. economic, environmental, political.

3 The number of people or organisations that benefit from the values is usually greater than those who invest in the infrastructure.

4 Different stakeholders derive different, and sometimes multiple, types of value.

5 The value captured varies over time and space. For example, the function of the flood defence for its purpose of protecting properties is only realised during a flood event at the point at which it is situated. Whereas the benefits of increased visitor numbers to an area or reduced insurance premiums are felt over a longer timescale and over a larger spatial extent.

6 Flood risk management infrastructure with multiple functions can unlock further value streams.

7 Interdependencies with other infrastructures emerge. For example, a new flood defence scheme may be built for the purpose of protecting other critical infrastructure such as wastewater treatment plants or railway embankments.

If these wider elements of value were to be exploited and captured, it can pave the way for alternative business models to emerge in practise. A first step is to help understand and identify the priorities and objectives of potential beneficiaries.

\section{Conclusions}

Alternative business models are required to bridge the current and expected long term funding gap for flood risk management infrastructure in England. Drawing from a review of over 100 alternative local infrastructure business models from around the world a number of alternative business models have been presented for flood risk management. These can open up a wider range of financing and funding options compared to the incumbent approach for flood risk management in England. Furthermore, the alternatives bring in additional actors and/or propose new governance arrangements to deliver and manage infrastructure.

A number of practical hurdles remain to transition to one of these alternative business models. Most importantly, our analysis shows that a crucial first step is the need to take a more systemic and longer term view to assessing infrastructure value. Investments should seek to exploit a much wider set of possible values identifying who benefits, how they benefit, where and when the benefit occurs and accrues, and mapping interdependencies that may offer further risks or opportunities. Ongoing work to be presented at the conference will include a full and detailed case study of surface water flood management infrastructure in Newcastle upon Tyne. Further work is focussing on the valuation of long term resilience, and future case studies will include a number of other international contexts and cultures.

\section{References}

1 Environment Agency (2014). Flood and coastal risk management - long term investment scenarios. Environment Agency, Bristol.

2 Bennet B. and Hartwell-Naguib (2014). Flood defence spending in England. Science and Environment Standard Note.

3 Bryson J., Pike A., Walsh C.L., Foxon, T., Bouch, C. Dawson, R.J. (2014). Infrastructure Business Models (IBM) Working Paper. Briefing Note No. 2.

4 Zott C., Amit R. and Massa M. (2011). The Business Model: Recent Developments and Future Research, Journal of Management 37, 1019-1042.

5 Baden-Fuller C. and Morgan M. (2010). Business Models, Long Range Planning 43, 156-171.

6 Zott C. and Amit R. (2008). The fit between product market strategy and business model: implications for firm performance, Strategic Mgmt. Journal 29, 1-26.

7 Teece D. (2010). Business models, strategy and innovation, Long Range Planning, 43, 172-194. 
8 Subacchi P., Pickford S., Tentori, D. and Huang H. (2014). Building Growth in Europe: innovative financing for infrastructure. The Royal Institute of International Affairs, London.

9 O'Brien P. and Pike A. (2015). The governance of local infrastructure funding and financing. Infrastructure Complexity, 2:3.

10 Helm D. (2010). Infrastructure and infrastructure finance: the role of the government and the private sector in the current world. In Straus H. (ed) Public and private financing infrastructure: policy challenges in mobilising finance. EIB.

11 National Audit Office (2014). Strategic flood risk management. National Audit Office, London.

12 Cabinet Office (2008). The Pitt Review: Learning lessons from the 2007 floods. Cabinet Office, London.

13 Defra (2015). Central Government Funding for Flood and Coastal Erosion Risk Management in England. Defra, London.

14 Helm D. (2015). Catchment management, abstraction and flooding: the case for a catchment systems operator and coordinated competition. Oxford University, Oxford.

15 Bryson J, Mulhall R, Song M, Loo B, Dawson RJ (in review). Conceptualising local infrastructure business models: the spatio-temporal fix. Research Policy.

16 http://ceg-research.ncl.ac.uk/ibuildDemo/

17 Environment Agency (2013). Cockermouth Cumbria. Profiling Partnership Funding. www.eacg.org.uk/Docs/PF/Cockermouth_PF_Profile_ final.pdf. 